\title{
PROVENIÊNCIA DOS MINERAIS DE ÓXIDOS DE Fe-Ti NAS AREIAS DA PRAIA DO PÂNTANO DO SUL, ILHA DE SANTA CATARINA (SC), SUL DO BRASIL
}

\author{
Edison Ramos Tomazzoli ${ }^{1}$, Ulisses Rocha de Oliveira² e Norberto Olmiro Horn Filho ${ }^{1}$ \\ Recebido em 20 maio, 2005 / Aceito em 1 setembro, 2006 \\ Received on May 20, 2005 / Accepted on September 1, 2006
}

\begin{abstract}
The sandy sediments of the Pântano do Sul beach, located in South coast of Santa Catarina island, have significant concentrations of heavy minerals, especially Fe-Ti oxides minerals (ilmenite and magnetite). In intention to discuss the source area of these minerals, comparison holding texture and chemistry of ilmenite and magnetite of the beach sediments and basic dykes was realized. Beach samples were impregnated, studied by thin sections and the electronic microprobe. The database includes 66 analysis from the beach sands and 72 from nearby outcrops. The use of electronic microprobe showed that ilmenite presents wide chemical variability and diverse provenance, originated from diabases and granitic and acid volcanic lithotypes that constitute the rocky coasts of the island. The ilmenite sandy sediments were arranged in four groups of similar chemical composition, correlationed to adjacent basic dykes. Considering the totality of ilmenite and magnetite grains; 4,6\% were derived from dike 1; 7\% from dike 2; 7\% from dike 3; 16,3\% from dike 4 and 55,8\% from another source, possibly from granitic or volcanic acid rocks, while $9,3 \%$ of the grains showed deriving from dike 3 or dike 4 . Therefore the chemical comparison of ilmenite in Pântano do Sul sandy sediments and lithotypes of the Santa Catarina island was very useful to determinate the sedimentary provenance of ilmenite sandy grains.
\end{abstract}

Keywords: provenance indicators, ilmenite, mineral chemistry, sandy beach.

RESUMO. Nos sedimentos arenosos da praia do Pântano do Sul, situada ao sul da ilha de Santa Catarina, ocorrem significativas concentrações de minerais pesados, principalmente minerais de óxidos de Fe-Ti (ilmenita e magnetita). Com o objetivo de discutir a proveniência desses minerais, fez-se uma comparação entre as texturas e a química de grãos de minerais de óxidos de Fe-Ti (ilmenitas e magnetitas) da areia praial e de minerais de óxidos de Fe-Ti de quatro diques básicos, eleitos como rochas fonte prováveis. Amostras de areia de praia foram impregnadas com resina e estudadas, sob a forma de lâminas delgadas e em microssonda eletrônica. Foram realizadas 66 análises micro químicas em areias de praia e 72 em afloramentos rochosos vizinhos. As análises químicas desses minerais, com microssonda eletrônica, mostraram que os grãos de ilmenita possuem um amplo espectro de variação de composição química, o que aponta para uma procedência variada, advinda não somente de diques básicos, mas provavelmente também de rochas graníticas e vulcânicas ácidas que constituem os costões rochosos da ilha. Composicionalmente, os grãos de ilmenita das areias agruparam-se em quatro conjuntos congruentes à composição química das ilmenitas dos quatro diques básicos acima referidos. Do total de grãos de ilmenita e magnetita analisados, 4,6\% apontaram para proveniência a partir do dique 1; 7\% do dique 2; 7\% do dique 3, 16,3\% do dique 4 e $55,8 \%$ de outras fontes, possivelmente rochas graníticas ou vulcânicas ácidas, enquanto que 9,3\% dos grãos mostraram-se provenientes ou do dique 3 ou do dique 4 . Portanto, a comparação da química mineral dos grãos de areia ilmenítica com a da ilmenita das rochas fonte mostrou ser um procedimento potencialmente muito eficaz na determinação da proveniência dos clastos.

Palavras-chave: indicadores de proveniência, ilmenita, química mineral, praias arenosas.

\footnotetext{
${ }^{1}$ Departamento de Geociências, CFH, Universidade Federal de Santa Catarina, Campus Universitário Trindade, Caixa Postal 476, 88040-970, Florianópolis, SC, Brasil -E-mails: edison@cfh.ufsc.br / horn@cfh.ufsc.br

2 Programa de Pós-graduação em Geografia, CFH, Universidade Federal de Santa Catarina, Campus Universitário Trindade, Caixa Postal 476, 88040-970, Florianópolis, SC. Brasil -E-mail: ulisseslicke@yahoo.com.br
} 


\section{INTRODUÇÃo}

A ilmenita é um mineral que muitas vezes ocorre em grandes concentrações nas areias de praia. Devido a sua grande variabilidade química na rocha-fonte, relacionada à oscilação nos teores de Fe, Mg, Mn e Ti, os grãos de areia ilmenítica podem ter sua procedência sedimentar determinada a partir da comparação de sua composição química com a da ilmenita presente nas rochas que constituem as áreas fonte primárias.

Nas areias praiais de Pântano do Sul, uma praia de enseada situada no sul da Ilha de Santa Catarina (Fig. 1), ocorre expressivo depósito de minerais pesados, com grande proporção em grãos negros de minerais de óxidos de Fe-Ti constituídos, predominantemente por ilmenita, que se dispõem em finas camadas escuras, intercaladas com camadas claras compostas, predominantemente, por grãos de quartzo (Fig. 2A). A estruturação dessas camadas está basicamente associada a origem de lâminas superficiais, onde 0 fenômeno de retrolavagem opera como fator seletivo (Clifton, 1969). Quando, em eventos de ressaca, a onda atinge a face da praia, transporta os sedimentos, ao mesmo tempo que parte da água se infiltra e retorna ao mar em subsuperfície, diminuindo 0 volume de água que reflui e diminuindo também a capacidade de transporte de sedimentos quando de retorno ao mar, formando depósitos residuais (Muehe, 2001), representados pelas camadas ricas em ilmenita e outros minerais pesados.

Com 0 objetivo de discutir a proveniência das ilmenitas e magnetitas do depósito praial de Pântano do Sul, realizou-se neste trabalho, uma comparação entre a textura e, principalmente, a química mineral de óxidos de Fe-Ti (ilmenitas e magnetitas) de areias praiais com as de quatro diques básicos que ocorrem no sul da Ilha de Santa Catarina, a distâncias variáveis da praia estudada (Fig. 1).

0 desenvolvimento e posterior aplicação dessa metodologia pode ser de grande utilidade em estudos de processos de transporte sedimentar, indispensáveis no manejo de áreas costeiras.

\section{CARACTERÍSTICAS DA ÁREA DE ESTUDO Contexto geológico local}

Geologicamente, o sul da ilha de Santa Catarina é constituído por maciços graníticos e de rochas vulcânicas ácidas, de idade neoproterozóica, cortadas por diques ácidos, também neoproterozóicos, bem como por diques básicos formados no Cretáceo. Os sedimentos de planície costeira unem o maciços rochosos e são constituídos por depósitos eólico, marinho praial, flúviolagunar e de leque aluvial (Caruso Jr., 1993), de idades cenozóicas (Fig. 1).

\section{Maciços graníticos/vulcânicos ácidos}

Os maciços graníticos são constituídos por granito eqüigranular médio a grosso, de coloração cinza a rósea, denominado Granito Illha, originalmente descrito por Scheibe \& Teixeira (1970), e integrante dos granitos alcalinos que compõem a Suíte Intrusiva Pedras Grandes (Zanini et al., 1997). Podem variar entre termos monzoníticos, sienograníticos e, subordinadamente, quartzo-monzoníticos e quartzo-sieníticos. Nessas rochas, os minerais essenciais são quartzo, feldspato alcalino $\mathrm{e}$ biotita (anfibólio); os acessórios são zircão, alanita, apatita e minerais de óxidos de Fe-Ti (magnetita/ilmenita); os secundários, epidoto, sericita/muscovita, clorita, titanita, carbonatos e fluorita. Datações $\mathrm{Rb}-\mathrm{Sr}$ revelaram idade isocrônica de $524 \pm$ $68 \mathrm{Ma}$ (Basei, 1985).

As rochas vulcânicas ácidas ocorrem, preferencialmente, no maciço rochoso que circunda a praia de Lagoinha do Leste (Fig. 1), e integram a unidade litoestratigráfica conhecida como Suíte Plutono-Vulcânica Cambirela. São constituídas por tufos e lapilli tufos ignimbríticos, intercalados com finos derrames de riolito fluidal. Essas rochas apresentam cristaloclastos de quartzo, K-feldspato e plagioclásio, com bordos angulosos ou arredondados e embaiados por reação com a matriz, usualmente vítrea ou muito fina, constituída, dominantemente, por quartzo e feldspato. Em alguns locais, exibem grandes concentrações de lapillis e bombas, as últimas com formas arredondadas, elipsóidicas ou retorcidas. Nessas rochas, os minerais essenciais são K-feldspato, quartzo e plagioclásio; os acessórios são biotita, epidoto, zircão, alanita e minerais opacos (minerais de óxidos de Fe-Ti); os secundários, clorita, sericita e carbonatos. Rochas da Suíte Plutono-Vulcânica Cambirela apresentaram idades isocrônicas (Rb-Sr) de $552 \pm 17 \mathrm{Ma}$ (Basei, 1985).

Diques de riolito, com espessuras métricas a decimétricas, ocorrem seccionando as rochas vulcânicas ácidas e também os granitos. Apresentam, geralmente, textura porfirítica, com fenocristais de quartzo e feldspatos, milimétricos a centimétricos, sob matriz muito fina ou afanítica, micrográfica ou microcristalina, composta por quartzo, K-feldspato, biotita, epidoto, anfibólio e apatita (Zanini et al., 1997).

Diques de composição básica formam o chamado Enxame de Diques Florianópolis. Apresentam dimensões variadas, desde pequenos diques centimétricos a métricos, até grandes diques com espessuras de mais de cem metros, que se prolongam, de forma descontínua, por dezenas de quilômetros. A grande maioria dos diques está orientada segundo a direção preferencial $\mathrm{N} 10^{\circ}$ $20^{\circ}$ E. Com menor freqüência, orientam-se segundo as direções 


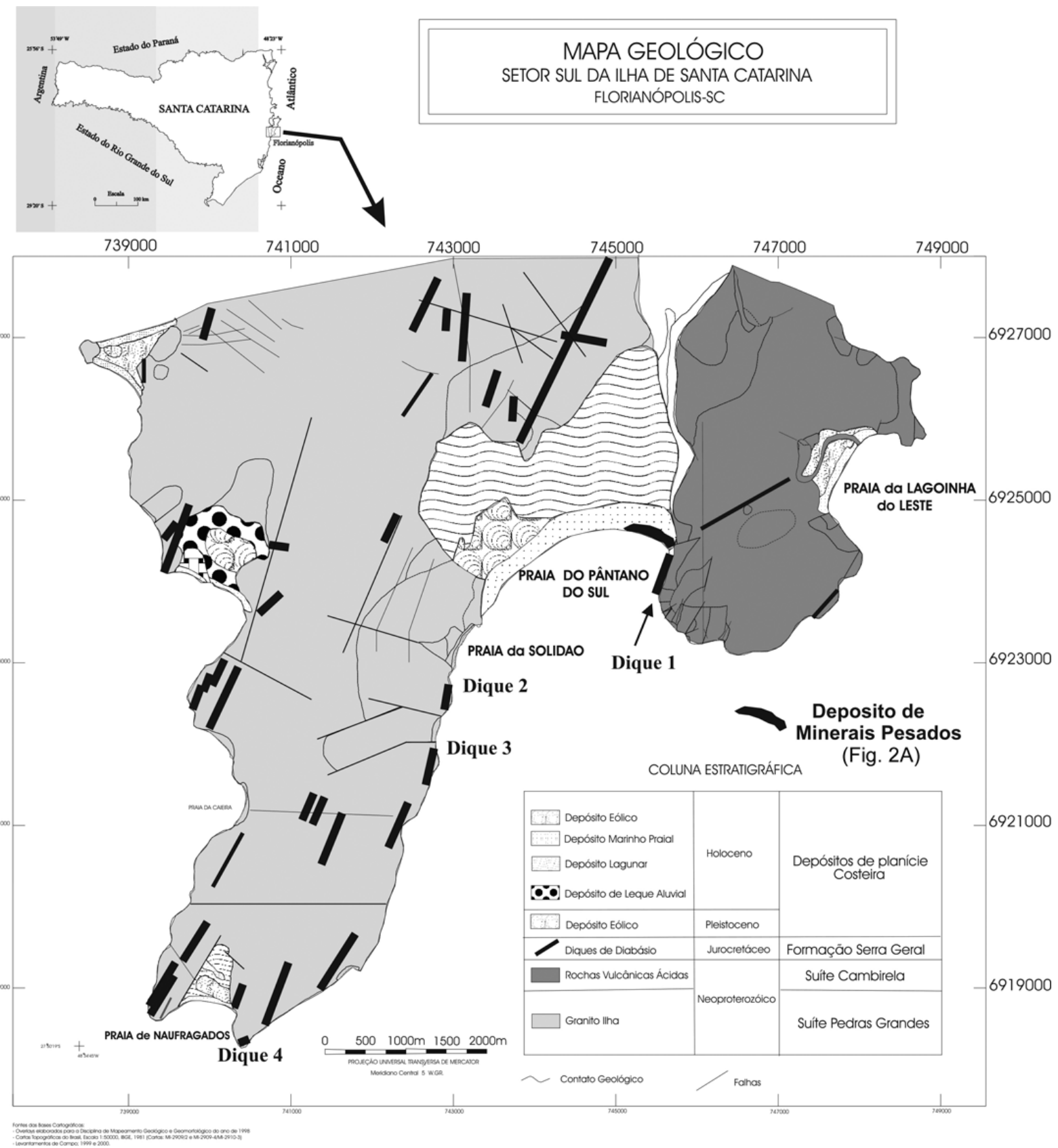

Figura 1 - Mapa geológico do sul da ilha de Santa Catarina (modificado de Tomazzoli \& Pellerin, 2001).

N20 ${ }^{\circ}-40^{\circ} \mathrm{W}$ e E-W. Os diabásios possuem textura variando de afanítica a porfirítica (mais rara), com o predomínio de trama intergranular fina, com cristais de piroxênio e óxidos de Fe-Ti envolvidos por plagioclásio tabular fino. No sul da Ilha de Santa Catarina foram reportados diques compostos, com bordos de diabásio e centro de riodacito, que representam diferenciados ácidos (Tomazzoli et al., 2005). Esses diques foram datados por Raposo et al. (1998) e Tomazzoli et al. (2005), que obtiveram idades entre 119 e $128 \mathrm{Ma}$, utilizando o método ${ }^{40} \mathrm{Ar} /{ }^{40} \mathrm{Ar}$.

\section{Depósitos da planície costeira}

A planície costeira do Pântano do Sul (Fig. 1) é constituída pelo sistema deposicional continental, composto por depósitos coluvial e de leque aluvial do Quaternário indiferenciado, e pelo sis- 
tema deposicional transicional, composto pelos depósitos marinho praial recoberto por depósito eólico do Pleistoceno superior e do Holoceno e depósitos lagunar e flúvio-lagunar do Holoceno (Gré et al., 1995).

Os depósitos coluvial e de leque aluvial apresentam-se na forma de rampas nas encostas dos morros do embasamento cristalino atingindo parte da planície costeira. São constituídos por sedimentos imaturos e mal selecionados, compostos por areias de granulometria grossa com seixos esparsos e matriz sílticoargilosa (Caruso Jr., 1993).

0 depósito marinho praial ocorre na forma de dois sistemas de cordões litorâneos. 0 de idade pleistocênica ocorre recoberto por dunas de mesma idade e localiza-se no segmento sudoeste da planície costeira onde está situada a praia de Pântano do Sul (Fig. 1). É constituído por areias de coloração amarronzada, impregnadas por óxido de ferro. 0 depósito marinho praial de idade holocênica é adjacente a todo o arco praial, sendo composto por areias finas quartzozas de coloração esbranquiçada, bege claro a amarela, contendo uma menor fração em minerais pesados dispostos em camadas plano-paralelas (Gré et al., 1995).

0 depósito eólico recobre superficialmente 0 depósito marinho praial, mantendo preservada a morfologia original de cristas e cavas. Nestes depósitos, predominam areias finas quartzosas, bem selecionadas, de coloração esbranquiçada. Nota-se também a presença de minerais pesados opacos (óxidos de Fe-Ti) marcando e evidenciando estratificações dos tipos plano paralela e cruzada destes depósitos (Fig. 2B).

\section{Dinâmica praial}

A praia do Pântano do Sul (Fig. 1) possui forma de enseada em planta, sendo limitada por maciços rochosos. É uma praia semiexposta à energia das ondas (Oliveira, 2004). Apresenta uma zona de sombra a nordeste, protegida da energia direta das ondas provenientes de nordeste-leste e leste-sudeste pelo costão rochoso. Neste trecho a linha de costa é mais curvada. No restante da praia, onde a linha de costa passa a ser mais retilínea, a praia é mais exposta à ação das ondas provindas de leste, como também de sul-sudeste (Oliveira, 2004). Observações das isóbatas da carta batimétrica Canal Sul de Florianópolis (DHN, 1977) indicam que a morfologia da antepraia da enseada do Pântano do Sul também varia ao longo do arco praial. Adjacente ao setor nordeste (zona de sombra) a antepraia é mais rasa que no restante da praia, provavelmente devido à presença de um banco submerso adjacente ao promontório rochoso.

A praia de Pântano do Sul está submetida ao regime de mi- cro marés, com altura máxima de 1,4 m e regime semidiurno. As maiores variações do nível do mar ocorrem devido a marés meteorológicas, definidas por Pugh (1987) como sendo a diferença entre a maré astronômica e a maré realmente observada. Quanto ao regime de ondas, ao longo do ano predominam ondulações de sul, com período em torno de 12 s e vagas de leste, com período de $8 \mathrm{~s}$. Durante o outono e inverno as ondulações de sul prevalecem sobre as vagas de leste, no verão há um balanço entre ambas as direções e na primavera prevalecem as vagas de leste. Condições de alta energia de onda estão, geralmente associadas a ondulações de sul/sudeste, com períodos de pico acima de $11 \mathrm{~s}$ e ondas maiores que $4 \mathrm{~m}$ em águas profundas, podendo ser encontradas em todas as estações do ano (Araújo et al., 2003). A incidência de ondas de tempestade, geralmente associada à direção sul/sudeste, gera empilhamento de água no Pântano do Sul (maré meteorológica positiva), processo favorecido pela a orientação NE-SW desta praia. Na zona de sombra (setor nordeste da praia) durante esses períodos de alta energia de onda não incidem ondas com altura significativa comparada aos outros setores da praia, embora seja observado um significativo avanço da maré (Oliveira, 2004), o que pode acarretar na destruição de propriedades e estruturas de contenção ali existentes.

Segundo Oliveira (2004), ao longo da praia do Pântano do Sul ocorre uma variação longitudinal no diâmetro médio dos sedimentos. No setor nordeste da praia, o diâmetro médio dos sedimentos oscila em torno de $0,162 \mathrm{~mm}$, predominando areias finas a muito finas. Nos setores central e sudoeste da praia, 0 diâmetro médio dos sedimentos é de 0,215 mm e 0,219 mm, respectivamente. Segundo esse autor, o tamanho dos sedimentos está provavelmente associado à variação na altura de onda ao longo da praia, com o diâmetro do grão progressivamente aumentando de nordeste para sudoeste. As maiores concentrações dos minerais de Fe-Ti nas areias de praia ocorrem no setor nordeste da praia do Pântano do Sul (zona de sombra), onde predominam areias de granulometria fina a muito fina (Oliveira, 2004). Concentrações de minerais pesados são encontrados em outras porções da praia, bem como ao longo da planície costeira adjacente, só que em menores proporções.

\section{MATERIAIS E MÉTODOS}

Os trabalhos de campo, realizados no setor nordeste da praia do Pântano do Sul, consistiram na abertura de 11 trincheiras no póspraia (Figs. 3A, 3B), onde foram coletadas 32 amostras indeformadas de sedimentos. As trincheiras tiveram espaçamento médio 

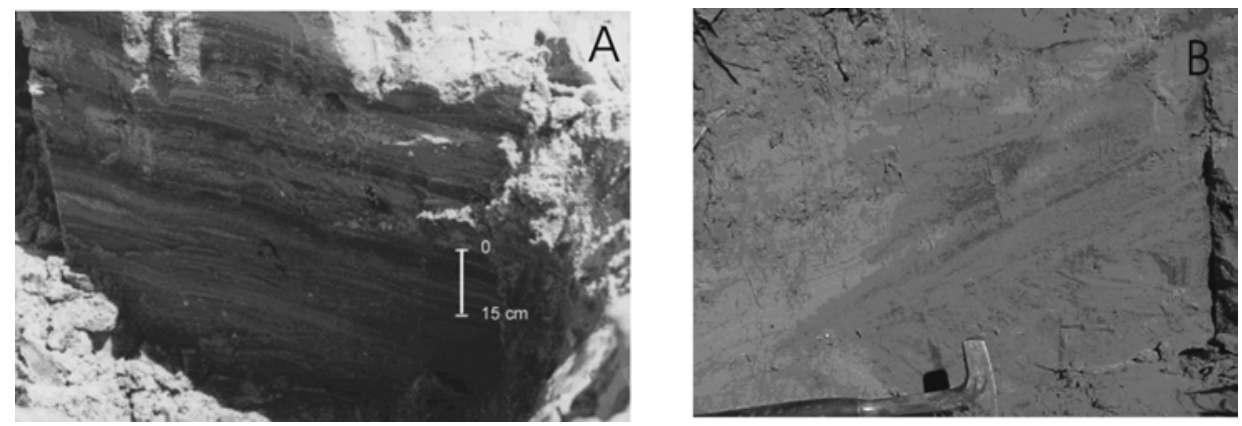

Figura 2 - (A) Trincheira mostrando a estruturação do depósito em camadas escuras, constituídas por grãos de minerais de óxidos de Fe-Ti, intercaladas por camadas claras, compostas, dominantemente por grãos de quartzo. (B) Estratificação cruzada em depósito eólico, marcada por camadas de minerais de óxidos de Fe-Ti.
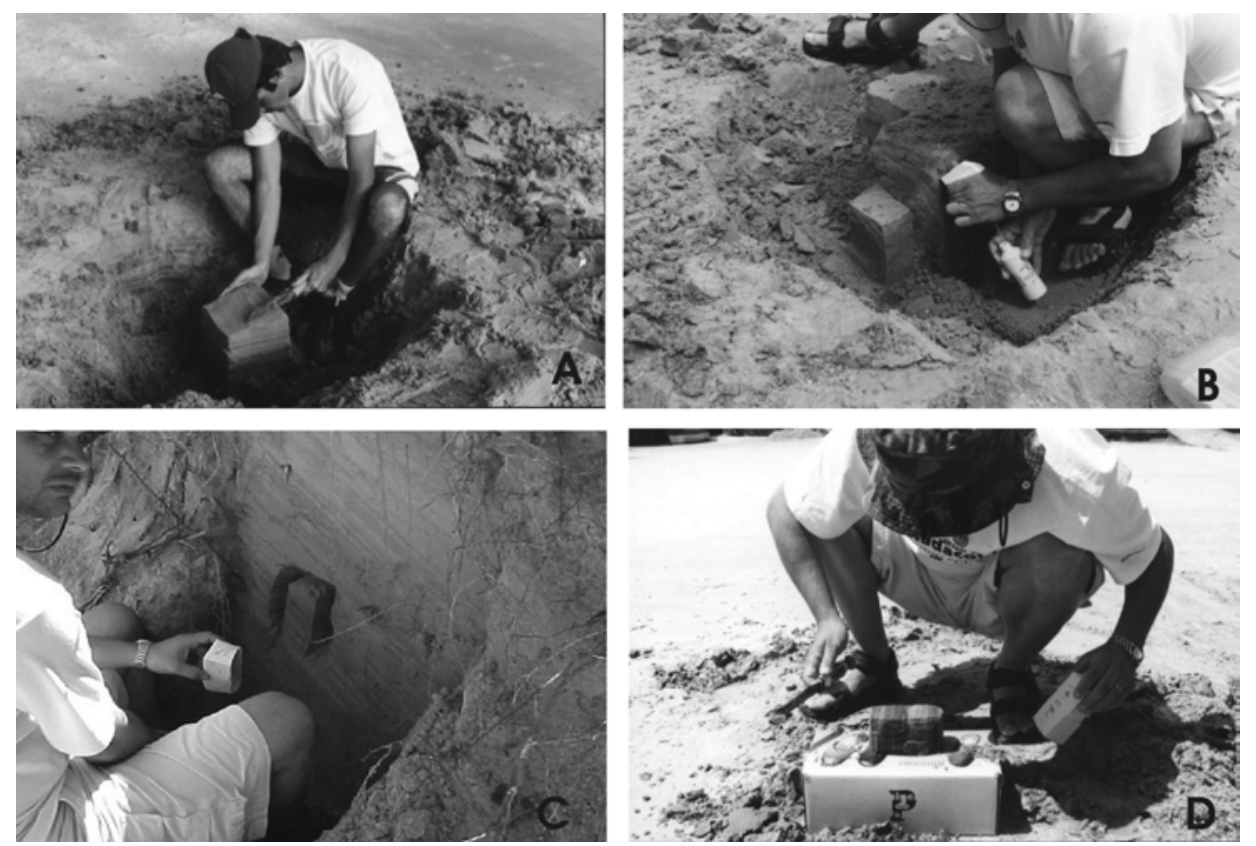

Figura 3 - Processo de coleta de amostras indeformadas.

de $30 \mathrm{~m}$ e foram escavadas até atingirem 0 lençol freático, encontrado a uma profundidade entre 0,5 e $1 \mathrm{~m}$. Foram coletadas, também, amostras indeformadas no depósito eólico do Holoceno (Fig. 2B).

Para coleta das amostras indeformadas procedeu-se à separação de pequenos volumes de sedimentos indeformados (Fig. 3C) que foram acondicionadas em pequenas caixas confeccionadas em cartolina, com cerca de $15 \mathrm{~cm} \times 8 \mathrm{~cm} \times 8 \mathrm{~cm}$ (Figs. 3C e 3D), para preservar suas estruturas. Antes do processo de coleta foi tomada a orientação espacial de cada amostra. Em laboratório, as amostras foram impregnadas com resina de poliéster, utilizando-se bomba de vácuo, seguindo-se os proce- dimentos descritos em Murphy (1976) e Castro (1985). Após a secagem da resina, as amostras foram serradas em fatias, segundo planos perpendiculares ao acamadamento. Lâminas delgadas polidas foram confeccionadas a partir destas fatias, seguindo-se a metodologia usual para esse procedimento (Hutchison, 1974). Nessas lâminas, foi possível, ao microscópio, visualizar estruturas sedimentares, além da disposiçã̃o original dos minerais pesados (Fig. 4).

Para fins comparativos, também foram confeccionadas lâminas delgadas polidas de possíveis áreas fonte, representadas por quatro diques básicos (dique 1, dique 2, dique 3, dique 4), reconhecidos no mapa geológico (Fig. 1). 

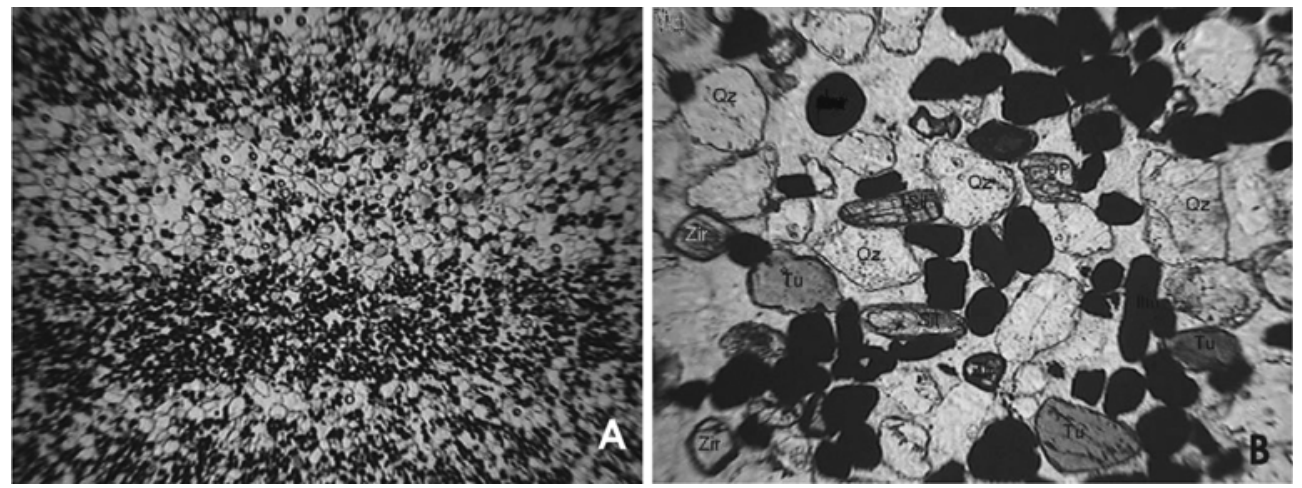

Figura 4 - (a) Fotomicrografia mostrando a estratificação plano paralela em depósito praial, marcada por camadas de concentração em óxidos de Fe-Ti. Luz natural polarizada (LN). Largura da foto $=6 \mathrm{~mm}$. (b) Detalhe da fotomicrografia anterior, mostrando a constituição mineralógica. Tu = turmalina; Qz = quartzo; Op = ilmenita; Sil = silimanita; Zir = zircão. Luz natural polarizada (LN). Largura da foto = 2 mm.

Tanto nas lâminas confeccionadas a partir dos diques de diabásio como nas das amostras indeformadas dos sedimentos arenosos praiais, procedeu-se à descrição petrográfica detalhada e à identificação dos minerais pesados por microscopia óptica (luz transmitida e refletida). Seguiram-se análises em microscópio eletrônico de varredura (MEV) com microssonda eletrônica EDS acoplada, com o objetivo de determinar, com maior precisão, possíveis texturas de intercrescimento entre óxidos de Fe-Ti. Em seguida, foram realizadas análises químicas de minerais com microssonda eletrônica WDS. No total, foram realizadas 72 análises químicas de óxidos de Fe-Ti de lâminas de diques e de 66 grãos de óxidos de Fe-Ti clásticos. Todas essas análises foram realizadas no Laboratório de Microssonda Eletrônica do Centro de Estudos em Petrologia e Geoquímica - IG-UFRGS. 0 equipamento utilizado foi o CAMECA SX50, composto por quatro espectrômetros tipo dispersão em comprimento de onda (WDS - wavelenght dispersive spectrometer). As análises foram realizadas com tensão de aceleração do feixe de $15 \mathrm{kV}$. Os valores de corrente (amperagem) e diâmetro do feixe (spot) foram, respectivamente, $25 \mathrm{nA} \mathrm{e} 1 \mu \mathrm{m}$. A descrições sobre equipamentos e técnicas de microscopia eletrônica de varredura (MEV) e de microssonda eletrônica podem ser obtidas em Gomes (1984) e Figueiredo (2000).

Micro-análises representativas dos minerais de óxidos de FeTi do depósito e dos diques, obtidas por microssonda eletrônica, foram reunidas na Tabela 1 onde, nas linhas iniciais, são colocadas as percentagens de óxidos (p. ex.: $\mathrm{SiO}_{2}, \mathrm{TiO}_{2}$ ). A partir dessas percentagens de óxidos, foram calculados os números de cátions da fórmula estrutural da ilmenita (na parte inferior da tabela), com base em 3 oxigênios, seguindo-se os procedimentos descritos em Deer et al. (1995). Segundo esses autores, a fórmula estrutural da ilmenita é $\mathrm{XYO}_{3}$, onde a posiçã̃o estrutural $X$ pode ser ocupada pelos cátios $\mathrm{Fe}^{+2}, \mathrm{Mg}$ ou $\mathrm{Mn}$, enquanto que a posição Y é geralmente ocupada pelos cátions $\mathrm{Ti}_{1} \mathrm{Fe}^{+3}$ ou Cr. Os cálculos das fórmulas estruturais e os gráficos/diagramas referentes ao quimismo mineral foram elaborados utilizando-se o programa Minpet 2.02 - Mineralogical and Petrological Data Processing System.

\section{RESULTADOS}

\section{Minerais de óxidos de Fe-Ti nos diques básicos}

0 dique 1 (Fig. 1) localiza-se próximo ao local onde foram coletadas as amostras de areias ricas em minerais de Fe-Ti. Esse dique possui espessura aproximada de 10 a $15 \mathrm{~m}$ e orientação $\mathrm{N} 10^{\circ} \mathrm{E}$. É constituído por diabásio com textura intergranular fina a média exibindo cristais de augita e de óxidos de Fe-Ti dispostos entre a trama de cristais tabulares de andesita-labradorita. A Mghornblenda pode ocorrer substituindo bordas de augita ou como grãos individuais. Os óxidos de Fe-Ti são constituídos, exclusivamente, por magnetita titanífera, sem texturas de intercrescimento.

0 dique 2, situado ao sul da praia da Solidão (Fig. 1), possui espessura aproximada de 30 a $40 \mathrm{~m}$ e orientação N10$15^{\circ} \mathrm{E}$. Também é constituído por diabásio, com textura intergranular fina a subofítica. Seus constitutivos minerais são andesinalabradorita, augita, hornblenda e minerais de óxidos de Fe-Ti. Esses últimos são formados por grãos monominerálicos de ilmenita ou por cristais compostos de magnetita com finas lamelas de oxi-exolução de ilmenita que se desenvolvem, muitas vezes, segundo as direções (111) da magnetita (Fig. 5a) e que correspondem às lamelas de oxi-exolução com padrão de treliça, descritas por Haggerty (1991). 
Tabela 1 - Análises representativas de ilmenitas dos diques estudados e do depósito sedimentar. Os valores relativos aos óxidos estão expressos em percentagem, enquanto que os valores relativos ao número de cátions da fómula estrutural da ilmenita, calculados com base em 3 oxigênios são expressos em números absolutos. As análises 9 e 10 representam clastos de ilmenita alterados por intemperismo.

\begin{tabular}{|c|c|c|c|c|c|c|c|c|c|c|}
\hline & \multicolumn{2}{|c|}{ Dique 2} & \multicolumn{2}{|c|}{ Dique 3} & \multicolumn{2}{|c|}{ Dique 4} & \multicolumn{4}{|c|}{ IImenita clástica } \\
\hline Análises & 1 & 2 & 3 & 4 & 5 & 6 & 7 & 8 & 9 & 10 \\
\hline $\mathrm{SiO}_{2}$ & 0,07 & 0,00 & 0,00 & 0,02 & 0,02 & 0,00 & 0,00 & 0,00 & 0,26 & 0,13 \\
\hline $\mathrm{TiO}_{2}$ & 49,22 & 49,15 & 50,30 & 50,76 & 50,68 & 49,59 & 46,73 & 44,48 & 66,63 & 59,76 \\
\hline $\mathrm{Al}_{2} \mathrm{O}_{3}$ & 0,18 & 0,08 & 0,03 & 0,02 & 0,06 & 0,04 & 0,12 & 0,16 & 0,42 & 0,38 \\
\hline $\mathrm{FeO}$ & 43,32 & 42,97 & 43,20 & 46,55 & 43,74 & 43,35 & 37,07 & 35,60 & 21,23 & 28,29 \\
\hline $\mathrm{Fe}_{2} \mathrm{O}_{3}$ & 4,38 & 4,93 & 4,03 & 0,00 & 3,61 & 5,45 & 11,71 & 15,94 & 0,00 & 0,00 \\
\hline $\mathrm{Cr}_{2} \mathrm{O}_{3}$ & 0,01 & 0,02 & 0,06 & 0,07 & 0,01 & 0,06 & 0,02 & 0,02 & 0,06 & 0,03 \\
\hline $\mathrm{MnO}$ & 1,04 & 0,95 & 0,51 & 0,42 & 0,43 & 0,42 & 1,24 & 0,67 & 2,20 & 3,75 \\
\hline $\mathrm{MgO}$ & 0,01 & 0,19 & 0,88 & 1,38 & 0,81 & 0,49 & 2,12 & 2,15 & 0,08 & 0,04 \\
\hline $\mathrm{CaO}$ & 0,01 & 0,01 & 0,03 & 0,01 & 0,02 & 0,02 & 0,03 & 0,04 & 0,20 & 0,02 \\
\hline Total & 98,24 & 98,3 & 99,04 & 99,21 & 99,37 & 99,42 & 99,04 & 99,05 & 91,08 & 92,4 \\
\hline $\mathrm{FeOt}$ & 47,70 & 47,90 & 47,33 & 46,55 & 47,35 & 48,80 & 48,78 & 51,54 & 21,23 & 28,29 \\
\hline $\mathrm{FeOt} / \mathrm{TiO}_{2}$ & 0,97 & 0,97 & 0,92 & 0,92 & 0,93 & 0,98 & 1,04 & 1,16 & 0,32 & 0,47 \\
\hline \multicolumn{11}{|c|}{ Cátions com base em 3 oxigênios } \\
\hline $\mathrm{Si}$ & 0,002 & 0,000 & 0,000 & 0,000 & 0,000 & 0,000 & 0,000 & 0,000 & - & - \\
\hline $\mathrm{Al}$ & 0,005 & 0,003 & 0,001 & 0,001 & 0,002 & 0,001 & 0,004 & 0,005 & - & - \\
\hline $\mathrm{Ti}$ & 0,953 & 0,950 & 0,960 & 0,972 & 0,964 & 0,946 & 0,886 & 0,845 & - & - \\
\hline $\mathrm{Fe}^{+2}$ & 0,932 & 0,924 & 0,917 & 0,991 & 0,925 & 0,920 & 0,782 & 0,752 & - & - \\
\hline $\mathrm{Fe}^{+3}$ & 0,085 & 0,095 & 0,077 & 0,000 & 0,069 & 0,104 & 0,222 & 0,303 & - & - \\
\hline $\mathrm{Cr}$ & 0,000 & 0,000 & 0,001 & 0,001 & 0,000 & 0,001 & 0,000 & 0,000 & - & - \\
\hline $\mathrm{Mn}$ & 0,023 & 0,021 & 0,011 & 0,009 & 0,009 & 0,009 & 0,027 & 0,014 & - & - \\
\hline $\mathrm{Mg}$ & 0,000 & 0,007 & 0,033 & 0,052 & 0,030 & 0,019 & 0,080 & 0,081 & - & - \\
\hline $\mathrm{Ca}$ & 0,000 & 0,000 & 0,001 & 0,000 & 0,001 & 0,000 & 0,001 & 0,001 & - & - \\
\hline$\sum$ Cations & 2,000 & 2,000 & 2,001 & 2,026 & 2,000 & 2,000 & 2,002 & 2,001 & - & - \\
\hline Xil & 0,896 & 0,883 & 0,883 & 0,942 & 0,895 & 0,875 & 0,704 & 0,654 & - & - \\
\hline Xhem & 0,082 & 0,091 & 0,074 & 0,000 & 0,067 & 0,099 & 0,200 & 0,263 & - & - \\
\hline Xgk & 0,000 & 0,007 & 0,032 & 0,049 & 0,029 & 0,018 & 0,072 & 0,070 & - & - \\
\hline Xpy & 0,022 & 0,020 & 0,011 & 0,009 & 0,009 & 0,009 & 0,024 & 0,012 & - & - \\
\hline
\end{tabular}

0 dique 3, localizado ao sul do dique 2 (Fig. 1), possui espessura em torno de $40 \mathrm{~m}$ e orientação N20E. Também é constituído por diabásio mas, ao contrário dos diques descritos anteriormente, exibe contatos irregulares e por vezes gradacionais com a rocha encaixante granítica, sugerindo uma interação subsólida entre ambas as rochas. É constituído, dominantemente, por plagioclásio, augita (às vezes substituída por hornblenda), hornblenda e minerais de óxidos de Fe-Ti, dispostos sob a forma de grãos monominerálicos de ilmenita ou de magnetita, ou ainda como grãos compostos, formados por bandas relativamente largas de ilmenita justapostas a bandas de magnetita (Fig. 5b). Estas bandas se diferenciam das lamelas de oxi-exolução do di- que 2 por serem mais espessas e por ocorrerem segundo uma única direção.

0 dique 4, situado no extremo sul da ilha de Santa Catarina (Fig. 1), possui espessura aproximada de $30 \mathrm{~m}$ e orientação $\mathrm{N} 30^{\circ}-40^{\circ} \mathrm{E}$ e é formado por diabásio eqüigranular fino a médio, com textura subofítica. Seus constitutivos mineralógicos essenciais são andesita-labradorita, augita e minerais de óxidos de Fe-Ti, estes últimos formados por grãos monominerálicos de ilmenita ou por grãos compostos, constituídos por subgrãos ou bandas espessas de magnetita e ilmenita. Menos freqüentemente, são observados grãos compostos constituídos por porções de ilmenita pura justapostas a porções de magnetita com finas lame- 

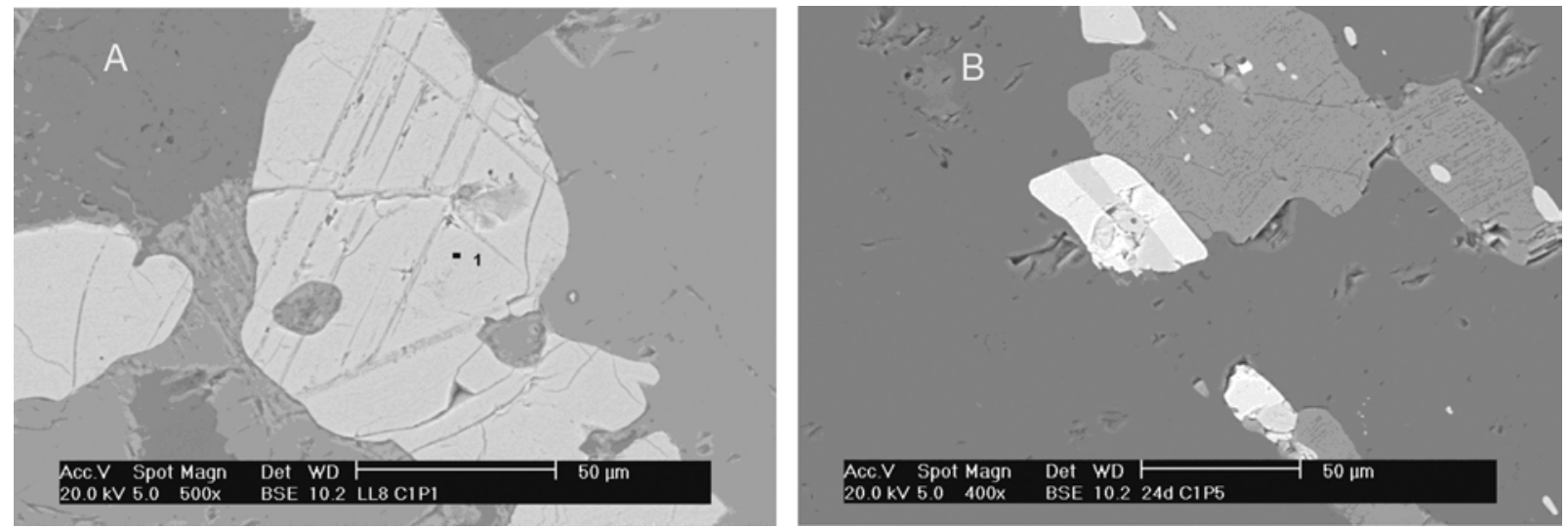

Figura 5 - Texturas de intercrescimento entre ilmenita e magnetita em grãos compostos. (A) Finas lamelas de oxi-exolução de ilmenita (mais escuras), com padrão em treliça. (B) Bandas mais largas de magnetita e ilmenita (mais escura), dispostas paralelamente. Imagens de microscopia eletrônica de varredura (MEV), modo retroespalhamento de elétrons.

las de oxi-redução de ilmenita, dispostas em três direções, semeIhantes às encontradas no dique 2.

\section{Minerais de óxidos de Fe-Ti no depósito praial}

A análise das seções verticais coletadas nas trincheiras durante o trabalho de campo (Fig. 6A), indicou a presença de areias predominantemente quartzosas intercaladas com poucos níveis com minerais pesados escuros, desde a superfície até 10 a $15 \mathrm{~cm}$ de profundidade. Abaixo dessa camada, aumenta a proporção de camadas com areias escuras, ricas em minerais de óxidos de Fe-Ti e outros minerais pesados, intercaladas com areias claras. Em algumas seções, abaixo das camadas ricas em minerais pesados, ocorreu camada formada por areias grossas (Fig. 6B), contendo materiais de origem tecnógena, como fragmentos de telhas e de tijolos.
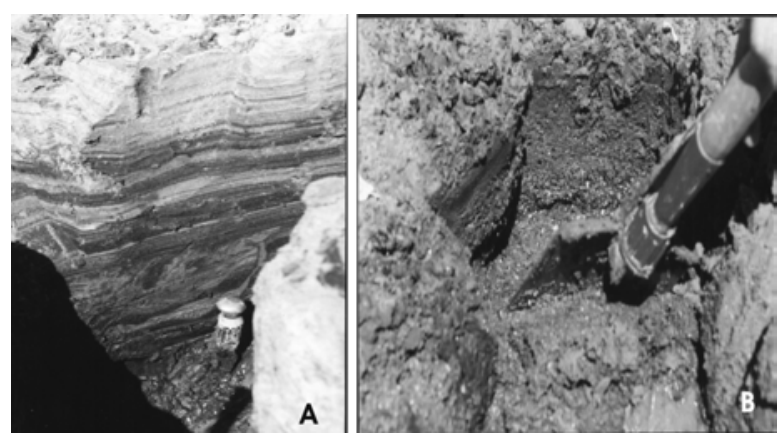

Figura 6 - (A) Camadas escuras, ricas em minerais de óxidos de Fe-Ti, intercaladas com camadas quartzosas claras. (B) Camada de areia grossa, com concentração de materiais de origem tecnógena.

As partículas de minerais pesados são arredondadas, com esfericidade variável e dispõem-se em finas camadas milimétri- cas a centimétricas, intercaladas com camadas claras com o predomínio de grãos arredondados e esféricos de quartzo (Fig. 4A). Nota-se que os grãos negros (de minerais de óxidos de Fe-Ti) possuem, freqüentemente, diâmetros médios menores que os minerais claros (Fig. 4B). Em geral, os grãos de quartzo se concentram na fração areia fina, enquanto os grãos de minerais de óxidos de Fe-Ti se concentram na fração areia muito fina.

Análises com microssonda eletrônica, apoiadas por observações e análises com microscópio eletrônico de varredura (com microssonda EDS acoplada) mostram que nas amostras coletadas no depósito de minerais pesados da praia do Pântano do Sul, cerca de $65 \%$ dos grãos de minerais de óxidos de Fe-Ti são constituídos por ilmenita monominerálica, e cerca de 30\% por grãos de ilmenita alterados por intemperismo. Por outro lado, grãos de magnetita titanífera monominerálica ocorrem em quantidade bem menor, perfazendo cerca de 5\% dos grãos de óxidos de FeTi. Não foram registradas ocorrências de grãos compostos, com textura de intercrescimento entre magnetita e ilmenita, como as observadas nos diques 2, 3 e 4 .

Além dos óxidos de Fe-Ti, a fração pesada é composta por grãos de zircão, turmalina, epidoto, anfibólio, titanita, silimanita e, mais raramente, por ortopiroxênio (Fig. 4B). As areias do depósito da duna frontal, adjacente ao depósito praial, podem exibir também finas camadas de areia rica em minerais de FeTi bem como outros minerais pesados. Essas finas camadas de areia mais escura tendem a destacar estruturas tipo estratificação cruzada (Fig. 2B), formadas como resultado do transporte eólico.

Os grãos de ilmenita alterados por intemperismo podem apresentar manchas mais claras, quando observados ao microscópio sob luz refletida, embora esta feição seja melhor observável ao 
MEV, no modo de retroespalhamento de elétrons; apresentam teores mais elevados em $\mathrm{TiO}_{2}$ e mais baixos em FeOt $(\mathrm{FeO}+$ $\mathrm{Fe}_{2} \mathrm{O}_{3}$ ), como pode ser observado nas análises 9 e 10 da Tabela 1. Para essas análises não há sentido em calcular o número de cátions da fórmula estrutural da ilmenita, com base em 3 oxigênios, uma vez que seus elementos já estão parcialmente reequilibrados para outras fases minerais de alteração, distintas da ilmenita. Análises desse tipo não foram consideradas neste estudo sobre proveniência.

Morad \& Aldahan (1986) mostram que a alteração intempérica da ilmenita se envolve a ocorrência de várias fases minerais intermediárias, sucessivamente enriquecidas em Ti e empobrecidas em $\mathrm{Fe}$ até atingir uma forma quase pura de $\mathrm{TiO}_{2}$. Portanto, as análises 9 e 10 da Tabela 1 com grande erro de fechamento (seus óxidos somam, respectivamente, 91,08 e 92,40\%) parecem representar fases intermediárias de alteração da ilmenita, com razões de $\mathrm{FeOt} / \mathrm{TiO}_{2}$ mais baixas e quimismo similar ao do mineral pseudo-rulito, um produto de alteração de ilmenita comum em praias.

$\mathrm{Na}$ figura 7 são apresentados os diagramas de variação de diversos óxidos em relação ao $\mathrm{TiO}_{2}$, para ilmenitas dos diques básicos e de areias praiais do Pântano do Sul. Observa-se que os teores em $\mathrm{TiO}_{2}$ em ilmenitas de diques básicos (diagramas à direita, na Fig. 7) apresentam uma pequena faixa de variação (entre 48,39 e 51,22\%), aspecto muito útil para a determinação da proveniência da ilmenita clástica (diagramas à esquerda, na Fig. 7), cujo intervalo de variação é muito mais amplo, oscilando entre 25,82 e 52,35\% (Tab. 2). 0 mesmo se aplica a $\mathrm{Al}_{2} \mathrm{O}_{3}$, FeOt e $\mathrm{MgO}$. Já $0 \mathrm{Cr}_{2} \mathrm{O}_{3}$ não se apresenta, neste caso, como bom discriminador de proveniência, visto que seus intervalos de variação em ilmenitas de diques básicos não diferem muito dos apresentados em ilmenitas clásticas.

Na Tabela 2 são apresentados os percentuais máximo e mínimo dos diversos óxidos analisados para as ilmenitas clásticas e diques básicos, enquanto que na Tabela 3 estão listados os coeficientes de correlação entre os principais óxidos analisados. 0 dique 1 não está representado nessa tabela, uma vez que não apresentou ilmenita, apenas magnetita titanífera.

A molécula de ilmenita pode ser visualizada como a justaposição entre diferentes proporções (frações molares) das moléculas de ilmenita - II $\left(\mathrm{FeTiO}_{3}\right)$, hematita - hem $\left(\mathrm{FeFeO}_{3}\right)$, geikielita - gk $\left(\mathrm{MgTiO}_{3}\right)$ e pyrophanita - py $\left(\mathrm{MnTiO}_{3}\right)$, como mostram, por exemplo, Deer et al. (1995). Na Figura 8 são apresentados os diagramas triangulares, envolvendo as frações molares de ilmenita (Xil), hematita (Xhem) e geikielita (Xgk).
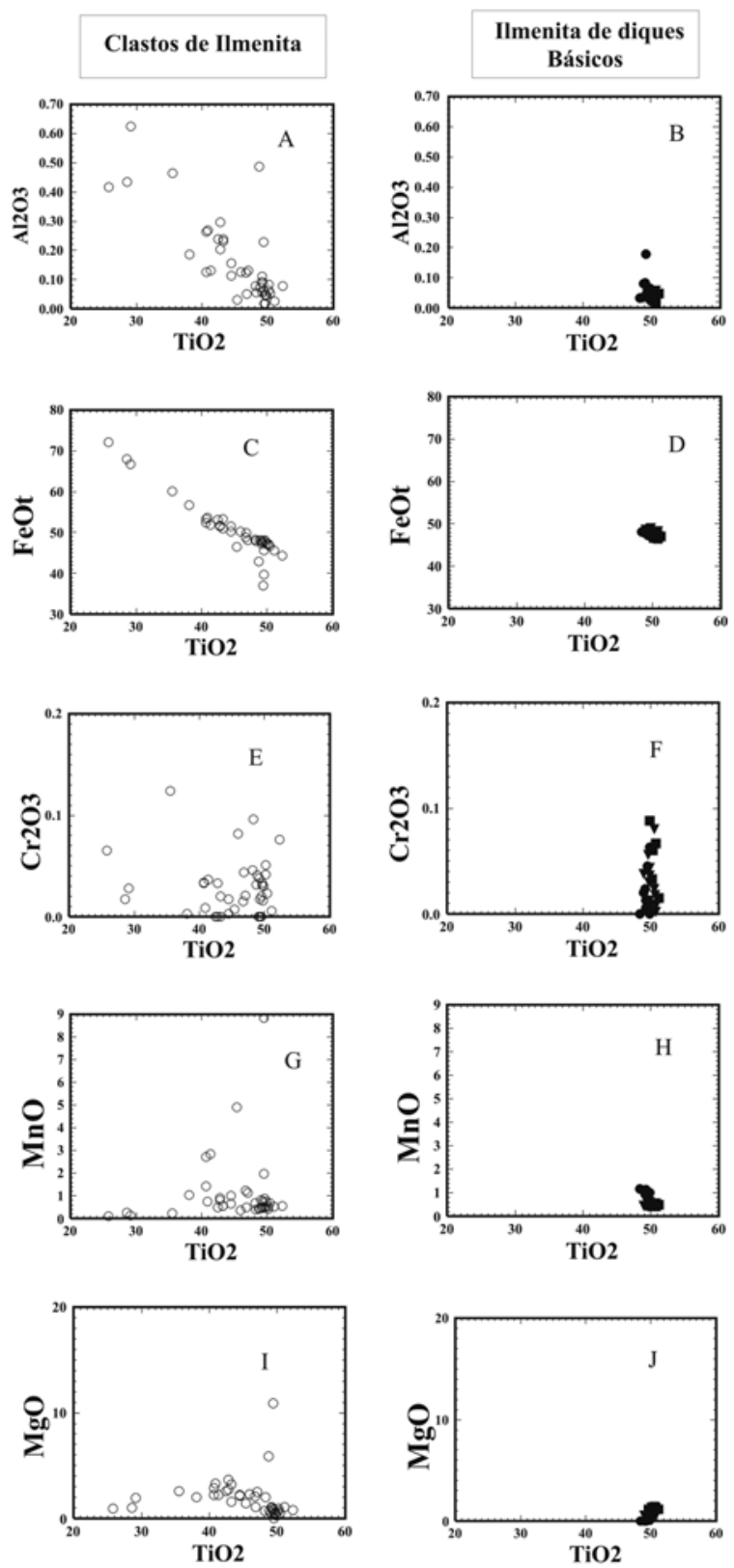

Figura 7 - Diagramas de variação percentual de diversos óxidos versus $\mathrm{TiO}_{2}$ de grãos de ilmenita do depósito praial (diagramas à esquerda) e de ilmenitas de diques básicos (diagramas à direita).

Na Figura 8A são apresentados os diagramas Xil-Xhem-Xgk para análises de diques básicos. A Figura 8B mostra a distribuição das amostras de ilmenita clástica (somente para os grãos isentos de alteração intempérica). Nesse diagrama, observa-se que a grande maioria das análises localiza-se fora do campo sombreado, que corresponde ao campo de ilmenitas de diques básicos. Essas análises representam ilmenitas por vezes bastante enriquecidas em FeOt e $\mathrm{MgO}$ e com teores mais baixos de 
Tabela 2 - Valores máximos e mínimos de óxidos analisados (valores em percentagem).

\begin{tabular}{|c|c|c|c|c|c|c|}
\hline \multicolumn{7}{|c|}{ Ilmenita clástica } \\
\hline & $\mathrm{TiO}_{2}$ & $\mathrm{Al}_{2} \mathrm{O}_{3}$ & $\mathrm{Cr}_{2} \mathrm{O}_{3}$ & $\mathrm{MnO}$ & $\mathrm{MgO}$ & Fe0t \\
\hline Mínim0 & 25,82 & 0,02 & 0 & 0,12 & 0,04 & 37,03 \\
\hline Máximo & 52,35 & 0,63 & 0,12 & 8,82 & 10,93 & 72,09 \\
\hline Número de classes & 41 & 41 & 41 & 41 & 41 & 41 \\
\hline \multicolumn{7}{|c|}{ Diques básicos } \\
\hline Mínimo & 48,39 & 0,02 & 0 & 0,42 & 0,01 & 46,55 \\
\hline Máximo & 51,22 & 0,18 & 0,09 & 1,17 & 1,46 & 49,06 \\
\hline \multicolumn{7}{|c|}{ Dique 2 } \\
\hline Mínimo & 48,39 & 0,03 & 0 & 0,76 & 0,01 & 47,2 \\
\hline Máximo & 49,84 & 0,18 & 0,05 & 1,17 & 1,19 & 48,07 \\
\hline Número de classes & 7 & 7 & 7 & 7 & 7 & 7 \\
\hline \multicolumn{7}{|c|}{ Dique 3 } \\
\hline Mínimo & 49,66 & 0,02 & 0,01 & 0,42 & 0,88 & 46,55 \\
\hline Máximo & 51,22 & 0,06 & 0,09 & 0,51 & 1,38 & 47,63 \\
\hline Número de classes & 6 & 6 & 6 & 6 & 6 & 6 \\
\hline \multicolumn{7}{|c|}{ Dique 4 } \\
\hline Mínimo & 48,97 & 0,02 & 0 & 0,42 & 0,31 & 46,88 \\
\hline Máximo & 50,74 & 0,06 & 0,08 & 0,62 & 1,46 & 49,06 \\
\hline Número de classes & 12 & 12 & 12 & 12 & 12 & 12 \\
\hline
\end{tabular}

Tabela 3 - Coeficientes de correlação dos principais óxidos analisados.

\begin{tabular}{|c|c|c|c|c|c|}
\hline \multicolumn{7}{|c|}{ Diagrama de correlação } \\
\hline & $\mathrm{TiO}_{2}$ & $\mathrm{Al}_{2} \mathrm{O}_{3}$ & $\mathrm{FeOt}$ & $\mathrm{Cr}_{2} \mathrm{O}_{3}$ & $\mathrm{MgO}$ \\
\hline $\mathrm{Ca} 0$ & 0,07 & 0,13 & $-0,15$ & $-0,17$ & 0,38 \\
\hline $\mathrm{MgO}$ & $-0,22$ & 0,49 & $-0,07$ & $-0,06$ & \\
\hline $\mathrm{Cr}_{2} \mathrm{O}_{3}$ & $-0,08$ & 0,07 & 0,15 & & \\
\hline $\mathrm{FeOt}$ & $-0,92$ & 0,69 & & & \\
\hline $\mathrm{Al}_{2} \mathrm{O}_{3}$ & $-0,82$ & & & & \\
\hline
\end{tabular}

$\mathrm{TiO}_{2}$, como mostram, também os diagramas da Figura 7. IImenitas desse tipo não foram encontradas em nenhum dos quatro diques básicos analisados, embora existam registros de ocorrência de ilmenitas ricas em Fe, Mg e Mn em rochas ácidas plutônicas e vulcânicas (Frost \& Lindsley, 1991).

A Figura $8 \mathrm{C}$ representa a parte superior do diagrama da Figura $8 \mathrm{~A}$, onde foram traçados os campos de distribuição das análises de ilmenita dos diques 2,3 e 4 . 0 dique 1 não é representado nesse diagrama, uma vez que não apresentou ilmenita, somente magnetita titanífera. Esses mesmos campos de distribuição de ilmenitas dos diques 2, 3 e 4 foram transportados para a Figura 8D que, por sua vez, representa 0 ápice do diagrama triangular da Figura 8B. Na Figura 8D, admite-se que os grãos de ilmenita clástica tiveram origem no dique em cujo campo suas análises encontram-se plotadas, devido à congruência entre suas composições químicas.

Dos 41 grãos de ilmenita e 2 grãos de magnetita titanífera analisados de amostras de areias da praia de Pântano do Sul, 4,6\% apontaram para uma proveniência do dique 1, 0 único dos diques analisados que não possui ilmenita e sim magnetita titanífera; $7 \%$ apontaram proveniência do dique 2, 7\% do dique 3 e 16,3\% do dique 4; 9,3\% apresentam características químicas que permitem associá-los tanto ao dique 3 como ao dique 4 (Tab. 4). A grande maioria dos clastos $(55,82 \%)$ tem outras áreas fonte, possivelmente as rochas graníticas e/ou vulcânicas ácidas que compõem a maior parte dos costões da região. 

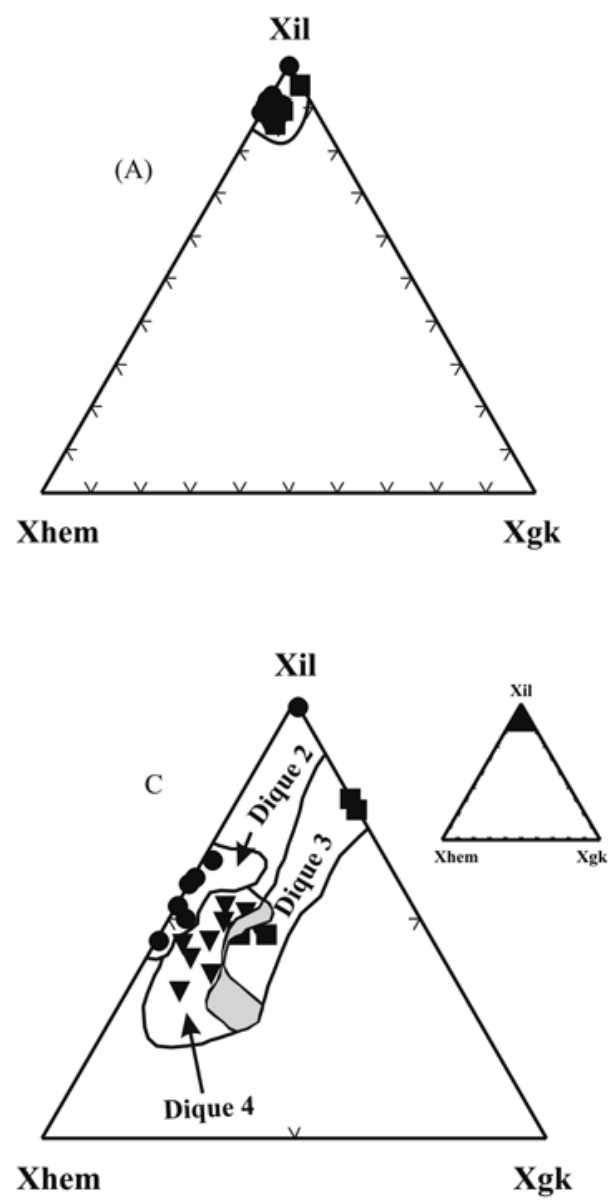
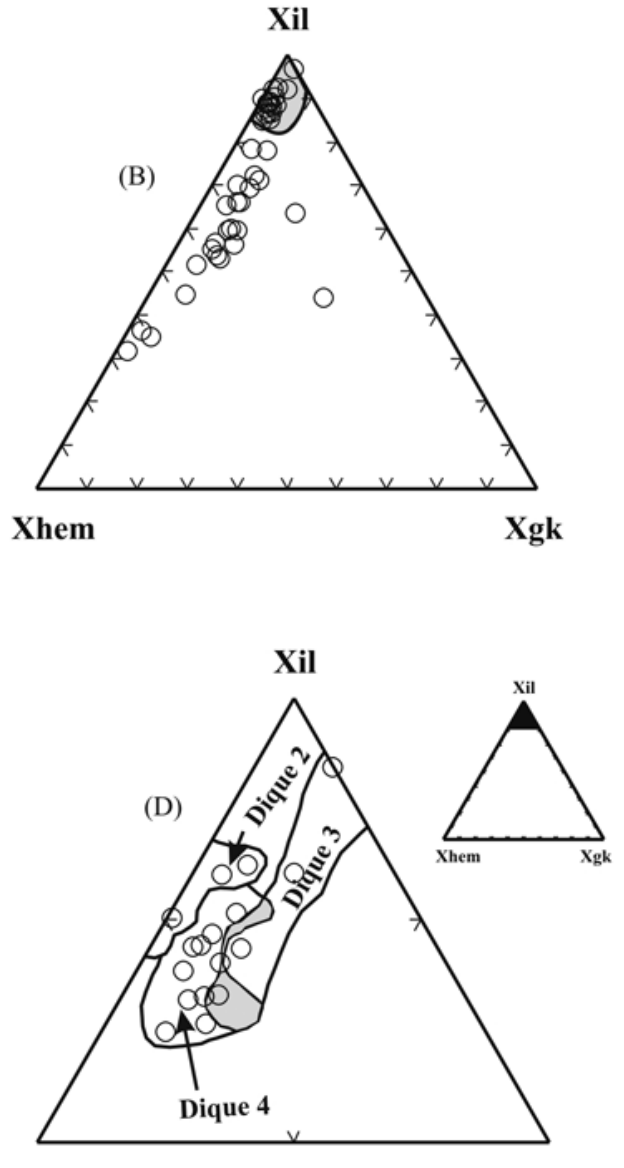

Xhem
Xgk

Figura 8 - Diagrama Xil-Xhem-Xgk da análises de ilmenita. (a) diagrama exibindo a distribuição de análise de ilmenitas de diques básicos; (b) distribuição das análises de ilmenita clástica (a área sombreada representa os campos de distribuição das ilmenitas de diques básicos); (c) ápice do diagrama a, mostrando os campos de distribuição das ilmenitas de diferentes diques básicos; (d) ápice do diagrama b, mostrando a distribuiç̧ão das ilmenitas clásticas em relação aos campos delimitados para os diques básicos do diagrama $c$ (a área sombreada representa os campos comuns aos diques 3 e 4).

Tabela 4 - Proveniência dos clastos de minerais de óxidos de Fe-Ti do depósito de minerais pesados da praia do Pântano do Sul.

\begin{tabular}{|c|c|c|}
\hline $\begin{array}{c}\text { Proveniência dos óxidos } \\
\text { de Fe-Ti clásticos }\end{array}$ & Número de casos & $\%$ \\
\hline Dique 1 & 2 & 4,60 \\
\hline Dique 2 & 3 & 7,00 \\
\hline Dique 3 & 3 & 7,00 \\
\hline Dique 4 & 7 & 16,28 \\
\hline Dique 3 ou Dique 4 & 4 & 9,30 \\
\hline $\begin{array}{c}\text { Granitos ou rochas } \\
\text { vulcânicas ácidas }\end{array}$ & 24 & 55,81 \\
\hline
\end{tabular}




\section{DISCUSSÃo}

\section{Avaliação do método}

A ilmenita tem sido apontada por diversos autores (p. ex., Basu \& Molinaroli, 1991; Grigsby, 1992) como um mineral muito útil em estudos de proveniência sedimentar, pois seus grãos sedimentares podem reter características químicas dos cristais da rocha fonte. IImenitas clásticas, provenientes de litotipos diversos, costumam apresentar diferenças químicas significativas. Por vezes, mesmo entre dois corpos rochosos do mesmo litotipo, podem ocorrer diferenças na composição química da ilmenita, relacionadas a processos de oxidação a alta e média temperatura. Essas características permitem identificar a fonte do grão sedimentar.

Estudos da proveniência sedimentar da ilmenita, a partir de sua composição química, vêm sendo realizados há muitos anos; no entanto, a relativa variabilidade química do mineral dificulta 0 estabelecimento de um procedimento padrão para 0 tratamento de dados, aplicável em diferentes regiões, com contexto geológico diversificado. Tratamentos estatísticos foram utilizados em diversos trabalhos (p. ex., Basu \& Molinaroli , 1989, 1991 e Grigsby, 1992), uma vez que se reconheceu não haver soluções gráficas simples para determinar a procedência dos grãos.

Para a área de estudo, o diagrama triangular das frações molares de ilmenita, hematita e geikielita (Xil-Xhem-Xgk) (Fig. 8) mostrou-se muito eficiente na correlação entre a química mineral das ilmenitas detríticas e a ilmenita da rocha fonte, podendo ser utilizado neste estudo de proveniência. A escolha dos índices Xil (extremo titanífero), Xhem (extremo ferroso) e Xgk (extremo magnesífero) para a confecção dos diagramas deu-se pela relação entre os limites máximo e mínimo de $\mathrm{TiO}_{2}$, FeOt e $\mathrm{MgO}$ entre as ilmenitas das areias e dos diques básicos (Tab. 2 e Fig. 7). Para esses três óxidos, as ilmenitas dos diques básicos apresentam intervalos relativamente pequenos entre os valores máximos e mínimos, quando comparados ao intervalo entre máximos e mínimos da ilmenita clástica (Tab. 2). Portanto, $\mathrm{TiO}_{2}$, FeOt e MgO são favoráveis a este estudo da proveniência, o que não acontece, por exemplo com $\mathrm{Cr}_{2} \mathrm{O}_{3}$, cujo intervalo nos diques (de $0 \mathrm{a}$ $0,09 \%$ ) é quase tão extenso como nas ilmenitas clásticas (de 0 a $0,12 \%$ ). Outro fator considerado na escolha desses três óxidos para a elaboração dos diagramas triangulares foi 0 fato de que esses elementos condicionam o comportamento geoquímico de outros. Na Tabela 3 é apresentado o diagrama dos coeficientes de correlação entre os diversos óxidos analisados. Observa-se, por exemplo, que $0 \mathrm{Al}_{2} \mathrm{O}_{3}$, apresenta forte correlação positiva com 0 $\mathrm{FeOt}$ e negativa com o $\mathrm{TiO}_{2}$. Isso significa que, nesse caso, o teor em $\mathrm{Al}_{2} \mathrm{O}_{3}$ na ilmenita é dependente dos teores em FeOte $\mathrm{TiO}_{2}$ : por isso, $0 \mathrm{Al}_{2} \mathrm{O}_{3}$ não deve ser utilizado, num diagrama triangular, em conjunto com esses óxidos, sob pena de haver redundância.

Na Figura 8B, observa-se que grande parte das análises de ilmenita clástica é plotada fora do campo relativo aos diques básicos. Supõe-se que a proveniência primária desses clastos seja de rochas graníticas ou vulcânicas ácidas dos costões, já que nesses litotipos costuma imperar, com mais freqüência que em rochas básicas toleíticas, condições de elevada fugacidade de oxigênio, que levam às chamadas alterações de alta temperatura da ilmenita. Haggerty (1991) descreve sete estágios progressivos de oxidação da ilmenita em alta temperatura (no ambiente magmático) com a formação, primeiramente, de ilmenita mais férrica antes da passagem para rutilo, titanohematita e pseudobrookita, que representam os estágios de maior oxidação.

A suposição de que os clastos de ilmenita férrica sejam decorrentes da alteração por intemperismo foi descartada, visto que a alteração intempérica da ilmenita atua no sentido inverso, ou seja, promove uma lixiviação de Fe e um aumento na concentração de Ti (Morad \& Aldahan, 1986).

\section{Proveniência dos minerais de óxidos de Fe-Ti da praia do Pântano do Sul}

A intercalação entre camadas quartzosas claras e camadas escuras, ricas em minerais pesados (Fig. 6A) parece estar associada à origem de lâminas superficiais, onde o fenômeno de retrolavagem opera como fator seletivo (Clifton, 1969). Quando a onda sobe a rampa que forma a face da praia, transporta os sedimentos, ao mesmo tempo em que parte da água se infiltra e retorna ao mar em subsuperfície, diminuindo o volume de água que reflui e o transporte de sedimentos de volta ao mar, formando depósitos residuais (Muehe, 2001). A Figura 9 demonstra um modelo empírico de deposição de minerais pesados em praias, associado à variação no regime de ondas formulado por Cascalho \& Taborda (2006). Segundo este modelo, a fase inicial (Fig. 9A), representa uma praia com areias claras e escuras. Durante um período de erosão do depósito, promovido pela significativa ação do refluxo das ondas, há transporte sedimentar da porção subaérea da praia para a porção subaquosa (Fig. 9B). Após o máximo estágio de remoção de areias, o perfil começa a recuperar seu estoque sedimentar, também pela ação do refluxo das ondas, fase em que a praia apresenta, em sua porção superficial, uma maior concentração de minerais pesados, com grande selecionamento dos grãos (Fig. 9C). Com a diminuição da energia de onda, a praia continua a recuperar seu estoque de sedimentos, formados por grãos de diferentes composições. Segundo Del Rio \& Shnack (1985), em períodos 


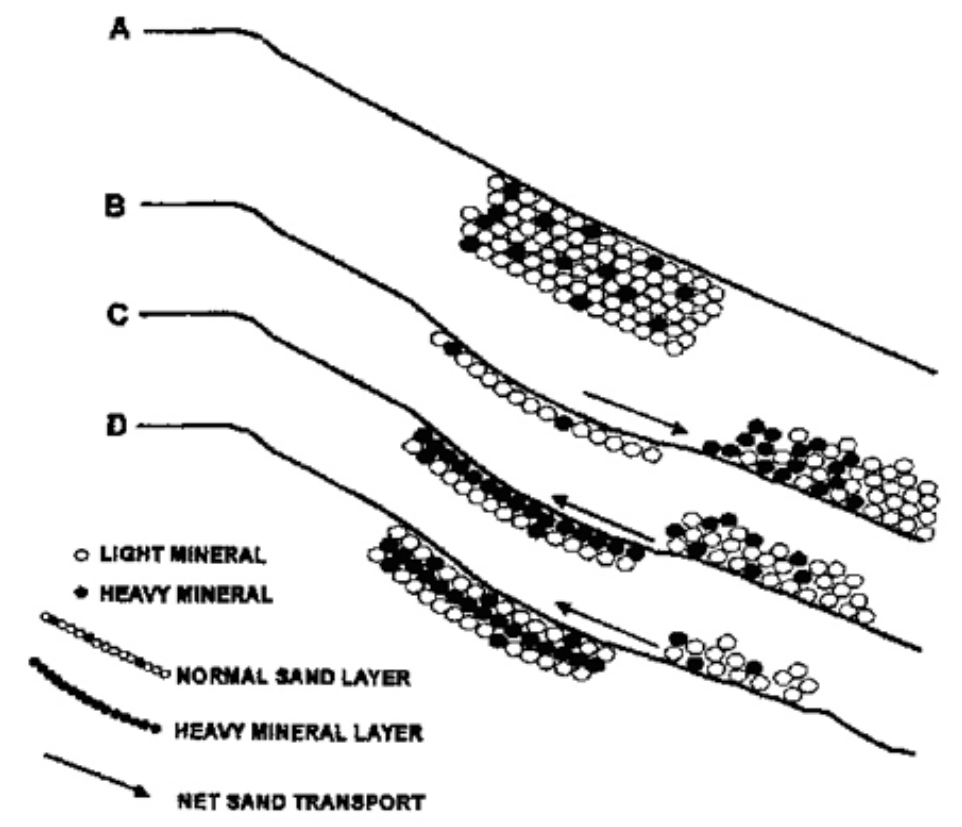

Figura 9 - Modelo empírico de deposição de minerais pesados em praias (Fonte: Cascalho \& Taborda, 2006).

em que ocorrem de tempestades o fenômeno de retrolavagem, responsável pelo processo seletivo dos minerais pesados, éacentuado.

A composição dos sedimentos trazidos à costa é redistribuída na direção da deriva litorânea resultante (Addad, 2001), bem como devido a processos de transporte sedimentar transversal à linha de costa. A areia mais grossa e o cascalho, geralmente ficam retidos em estuários ou lagunas ou são depositados em praias próximas, enquanto que os sedimentos mais finos são levados deriva abaixo. Os minerais pesados acompanham esse padrão. Komar \& Wang (1984) indicam que os processos seletivos como ondas e correntes selecionam os minerais pesados de acordo com seu tamanho, densidade e forma, tanto paralela como transversalmente à linha de costa. Áreas erodidas estão associadas a sedimentos mais ricos em seu conteúdo total de minerais pesados. Como resultado será formado um depósito residual constituído por sedimentos quartzosos de maior tamanho e minerais pesados de maior densidade que, em geral, se concentram nas frações areia fina e muito fina.

Supõe-se que a concentração de minerais de óxidos de Fe-Ti e outros minerais pesados, no setor nordeste da praia do Pântano do Sul, esteja associada a três aspectos: (1) concentração dos minerais pesados nas areias fina a muito fina, como ocorre ao longo das praias de toda a ilha de Santa Catarina (Martins et al., 1970); (2) concentração de areias fina a muito fina (e minerais pesados) associada à baixa atividade hidrodinâmica neste setor (depósito residual) e (3) erosão da praia de Pântano do Sul, o que acentuaria a exposição dos minerais pesados em superfície. Evidências erosivas ao longo da praia do Pântano do Sul foram diagnosticadas pelo registro de danos a propriedades (Simó, 2003), presença de estruturas de contenção à erosão e freqüente ocorrência de escarpas na duna frontal.

Um outro aspecto a ser considerado é que ao longo da praia de Pântano do Sul predominam correntes Iongitudinais no sentido SW para NE, relacionadas ao fato de as ondulações dominantes na região virem de sul/sudeste (Araújo et al., 2003; Oliveira, 2004). Além disso, a menor altura de onda encontrada no setor nordeste promove a geração de correntes do setor sudoeste, mais exposto, para o nordeste, mais abrigado, uma vez que variações na altura de onda ao longo de uma praia de enseada podem gerar correntes litorâneas da porção mais exposta para a mais abrigada da praia (Bascom, 1951). Diferenças no diâmetro do grão ao longo de praias de enseada foram primeiramente investigadas por esse autor. Ele mostra que, ao longo de uma mesma praia, que recebe sedimentos de uma mesma área fonte, o diâmetro do grão aumenta conforme aumenta a energia das ondas. As características da antepraia observadas na carta batimétrica (DHN, 1977) indicam que esta área da enseada é uma provável área de deposição sedimentar residual. A forma e o posicionamento espacial do setor nordeste do arco praial, com con- 


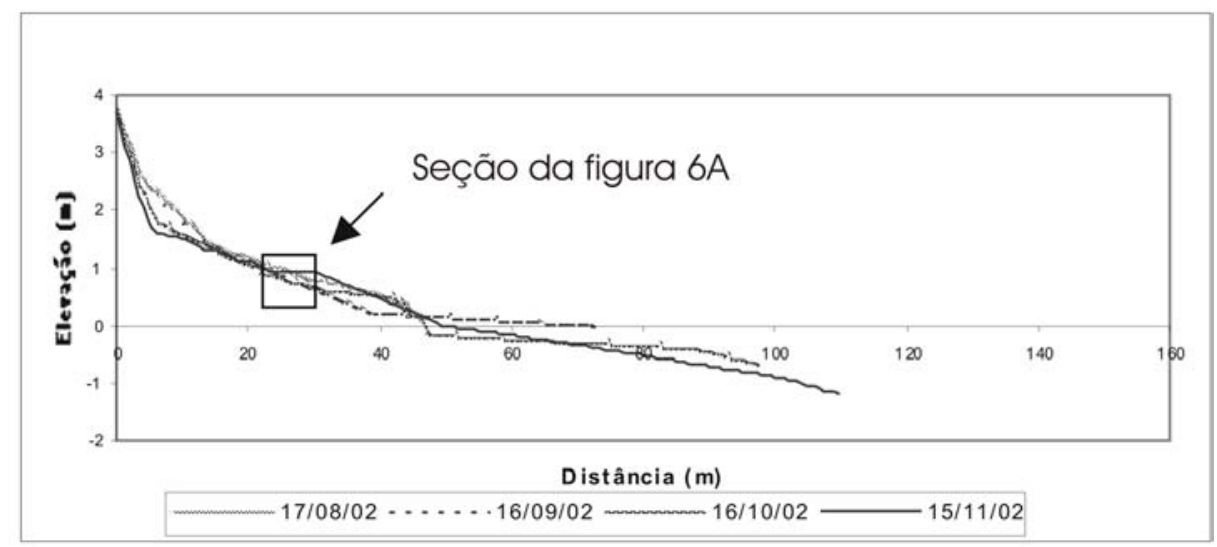

Figura 10 - Perfis de praia realizados na praia do Pântano do Sul entre agosto e novembro de 2002. (Fonte: Oliveira, 2004).

cavidade voltada para sudoeste (Fig. 1) parecem funcionar como uma espécie de "armadilha", retendo os sedimentos provindos daquela direção.

A correlação inicial entre a rocha fonte primária e os depósitos de minerais de óxidos de Fe-Ti encontrados no setor nordeste da praia do Pântano do Sul deve ter sido influenciada pelos inúmeros processos de transporte sedimentar desde a sua retirada da rocha fonte primária. Entres estes processos destacam-se as oscilações do nível relativo do mar. Ao longo dos últimos 120.000 anos (do Pleistoceno superior ao Holoceno), há registros destas variações na planície costeira da ilha de Santa Catarina (Caruso Jr., 1993).

Em períodos em que o nível do mar se encontrava abaixo do atual, depósitos de minerais pesados podem ter se formado na margem da plataforma continental e, em determinados casos, com a subseqüente elevação do nível marinho, muito desses depósitos foram soterrados por sedimentos transgressivos (Kudras, 1987, 2000 apud Murton, 2000). A posterior exposiç̧ão destes depósitos possibilitou seu retrabalhamento pela ação das correntes e das ondas, sendo depositados nas praias como resultado da migração transgressiva da atual linha de costa (Souza, 2004). No entanto, apesar de todos estes processos, foi possível estabelecer uma boa correlação geoquímica entre os minerais de óxidos de Fe-Ti da praia do Pântano do Sul com os de diques analisados, possibilitando um elo de ligação entre a fonte primária e 0 sedimento atualmente depositado.

Através da medição de perfis de praia na área de estudo (Fig. 10), pôde-se associar a camada superficial predominantemente clara do pós-praia ao desenvolvimento de uma berma na praia nos meses anteriores à coleta (outubro e novembro de 2002) durante um período de baixa energia hidrodinâmica na área (Oliveira, 2004). As camadas de areias claras intercaladas com areias escuras (Fig. 6A) foram depositadas em períodos anteriores à formação da berma.

\section{CONCLUSÕES}

Por muitas décadas considerou-se que os grãos de ilmenita encontrados na praia do Pântano do Sul fossem provenientes de um dique de diabásio localizado no limite com 0 depósito (dique 1, Fig. 1). Essa idéia era reforçada pelo fato de que o referido dique constituir parte do costão diretamente voltado para o depósito que, por sua vez, encontra-se num setor de baixa hidrodinâmica.

Análises de microssonda eletrônica mostraram, contudo, que os clastos de ilmenita possuem um amplo espectro de variação química, o que aponta para uma procedência variada, advinda não somente de diabásios, como principalmente de rochas graníticas e vulcânicas ácidas que constituem os costões rochosos da região, implicando num processo de transporte mais longo e mais complexo. Por sua vez, o dique 1 contribui apenas com cerca de 4,6\% dos óxidos de Fe-Ti encontrados na praia. Os diques de diabásio contribuíram com cerca de 44\% dos óxidos de Fe-Ti analisados na praia de Pântano do Sul (Tab. 4), uma proporção bastante elevada, considerando-se a reduzida área de exposição atual dos diques nos costões, em relação às rochas graníticas.

Inicialmente supunha-se que as texturas de intercrescimento (ou de oxi-exolução) entre ilmenita e magnetita, presentes em algumas dessas rochas fonte fossem úteis como indicadores secundários das fontes sedimentares; entretanto, observou-se que os clastos de ilmenita e magnetita do depósito praial são monominerálicos sem texturas de intercrescimento como as que ocorrem nos diques 2,3 e 4, provavelmente devido a uma menor resistência dos grãos poliminerálicos à degradação num ambiente marinho de alta energia. 
Dentre os diques básicos estudados, foi o dique 4, justamente o mais distante da praia do Pântano do Sul, que demonstrou ter dado uma maior contribuição ao depósito (16,3\%). Provavelmente, sua localização, num ambiente de alta energia de onda, o torne mais suscetível à erosão e a um fornecimento sedimentar maior.

Apesar do pequeno número de análises, a metodologia apresentada mostrou grande potencial para a identificação da rochafonte dos grãos de areia ilmenítica. Com o posterior desenvolvimento e aprimoramento do método, poderá ser avaliado o seu emprego em trabalhos de modelamento de correntes de deriva litorânea.

\section{REFERÊNCIAS}

ADDAD JE. 2001. Minerais pesados: uma ferramenta para prospecção, proveniência, paleogeografia e análise ambiental. Edição Independente. $80 \mathrm{pp}$.

ARAÚJO CES, FRANCO D, MELO FILHO E \& PIMENTA F. 2003. Wave regime characteristics of southern Brazilian coast. Anais VI International Conference on Coastal and Port Engineering in Developing Countries, COPEDEC, Paper No. 97, 15 pp. CD-ROM. Colombo, Sri Lanka.

BASCOM WN. 1951. The relationship between sand-size and beach face slope. Trans. Am. Geographics. Union, (SI), 32: 866-874.

BASEI MAS. 1985. 0 cinturão Dom Feliciano em Santa Catarina. Tese de Doutorado, Universidade de São Paulo, 185 pp.

BASU A \& MOLINAROLI E. 1989. Provenance characteristics of detrital opaque Fe-Ti oxide minerals. Journal of Sedimentary Research, 59(6): 922-934.

BASU A \& MOLINAROLI E. 1991. Reliability and applications of detrital opaque Fe-Ti oxide minerals in provenance determination. In: Developments in Sedimentary Provenance Studies (MORTON AC, TODD SP \& HAUGHTON PDW, eds.). Geological Society Publications 57: 55-65.

CARUSO Jr F. 1993. Mapa geológico da ilha de Santa Catarina - Escala 1: 100.000. Texto explicativo e mapa. Notas Técnicas, 6: 1-28.

CASCALHO JPV \& TABORDA RPM. 2006. Heavy mineral placer formation - An example from Algarve, Portugal. Journal of Coastal Research, Proceedings of the $8^{\text {th }}$ International Coastal Symposium, Itajaí, SC, Brazil. SI 39: 246-249.

CASTRO SS. 1985. Impregnação de amostras de solo para confecção de lâmina delgada. SBCS. Bol. Informativo, 44 pp.

CLIFTON HE. 1969. Beach lamination: Nature and origin. Marine Geology, 7(60): 553-559.

DEER WA, HOWIE RA \& ZUSSMAN J. 1995. An introduction to the rock forming minerals. London, Longman, $696 \mathrm{pp}$.
DEL RIO JL \& SHNACK EJ. 1985. Efectos de tormenta en la depositación selectiva de minerales pesados en playas. Revista de la Asociación Argentina de Mineralogía, Petrología y Sedimentología, 16(4): 27-33.

DHN. DIRETORIA DE HIDROGRAFIA E NAVEGAÇÃO. 1977. Carta Náutica 1904: Canal Sul de Santa Catarina. Escala 1:49.918.

FIGUEIRED0 BR. 2000. Minérios e Ambiente. Editora Unicamp. Campinas, São Paulo. 401 pp.

FROST BR \& LINDSLEY DH. 1991. Occurrence of iron-titanium oxides in igneous rocks. In: LINDSLEY DH (Ed.). Oxide Minerals Petrologic and Magnetic Significance. Reviews in Mineralogy, 25: 433-462.

GOMES CB. 1984. Técnicas analíticas instrumentais aplicadas à geologia. Ed. Edgard Blücher. São Paulo. 218 pp.

GRÉ JCR, ABREU DE CASTILHOS J \& HORN FILHO NO. 1995. Quaternary deposits of the Pântano do Sul beach, Santa Catarina island, Brazil. In: ARGOLLO J \& MOURGUIART P (Ed.). Climas Cuaternários en América del Sur. La Paz, Bolivia, 7: 121-131.

GRIGSBY JD. 1992. Chemical fingerprint in detrital ilmenite: a viable alternative in provenance research? Journal of Sedimentary Research, 62(2): 331-337.

HAGGERTY SE. 1991. Oxide Textures - a Mini Atlas. In: LINDSLEY DH (Ed.). Oxide Minerals Petrologic and Magnetic Significance. Reviews in Mineralogy, 25: 128-218.

HUTCHISON CS. 1974. Laboratory Handbook of Petrographic Techniques. John Wiley \& Sons. New York. 527 pp.

KOMAR PD \& WANG C. 1984. Processes of selective grain transport and the formation of placer on beaches. Journal of Geology, 92: 637-655.

MARTINS LRS, GAMERMANN N, SCHEIBE LF \& TEIXEIRA VH. 1970. Sedimentologia da ilha de Santa Catarina. I - Areias praiais. Publicação Especial da Escola de Geologia, Porto Alegre, 18: 1-55.

MORAD S \& ALDAHAN AA. 1986. Alteration of detrital Fe-Ti oxides in sedimentary rocks. Geological Society of America Bulletin, 97: 567-578.

MUEHE D. 2001. Geomorfologia costeira. In: GUERRA AJT \& CUNHA SB (Ed.). Geomorfologia: uma atualização de bases e conceitos. Editora Bertrand Brasil, 4, Rio de Janeiro. 253-308.

MURPHY CP. 1976. Thin section preparation of soils and sediments. A.B. Academic Publishers. United Kingdom. 149 pp.

MURTON BJ. 2000. A Global review of non-living resources on the extended continental shelf. Revista Brasileira de Geofísica, 18(3): 281-306.

OLIVEIRA UR. 2004. Comportamento morfodinâmico e granulometria do arco praial Pântano do Sul - Açores, ilha de Santa Catarina, SC, Brasil. Dissertação de Mestrado. Programa de Pós-graduação em Geografia, Universidade Federal de Santa Catarina, 102 pp.

PUGH DT. 1987. Tides, surges and mean sea level. John Wiley \& Sons. Chichester, U.K. 486 pp. 
RAPOSO MIB, ERNESTO M \& RENNE PR. 1998. Paleomagnetism and ${ }^{40} \mathrm{Ar} /{ }^{39} \mathrm{Ar}$ dating of the early Cretaceous Florianópolis dike swarm. Physics of the Earth and Planetary Interiors, 108(4): 275-290.

SCHEIBE LF \& TEIXEIRA VH. 1970. Mapa topogeológico da ilha de Santa Catarina. Porto Alegre. DNPM.

SIMÓ DH. 2003. Caracterização e distribuição das "ressacas" e áreas de risco na ilha de Santa Catarina, SC, Brasil. Monografia de conclusão de curso de bacharelado em Geografia. Departamento de Geociências, Universidade Federal de Santa Catarina. 130 p.

SOUZA DR. 2004. Minerais pesados na plataforma continental interna adjacente ao litoral centro norte de Santa Catarina. Trabalho de Graduação, 103 pp. UNIVALI, Itajaí, Santa Catarina.
TOMAZOLLI ER \& PELLERIN JGM. 2001. Aspectos geológico-geomorfológicos do sul da ilha de Santa Catarina. Anais $8^{\circ}$ Encontro de Geógrafos da América Latina, 3: 8-14. CD-ROM. Santiago, Chile.

TOMAZZOLI ER, MIZUSAKI AMP, LIMA EF, FÉLIX A, FIGUEIREDO AMG. 2005. Rochas Ácidas Associadas ao Enxame de Diques Florianópolis na Ilha do Arvoredo e na Ilha de Santa Catarina (SC): Dados Geocronológicos Preliminares. Anais III Simpósio de Vulcanismo e Ambientes Associados. CD-ROM. Cabo Frio, Rio de Janeiro.

ZANINI LFP, BRANCO PM, CAMOZZATTO E \& RAMGRAB GE (Ed.). 1997. Programa de Levantamentos Geológicos Básicos do Brasil, FoIhas Florianópolis/Lagoa, SG. 22-Z-D-V/IV, Estado de Santa Catarina: Escala 1:100.000. Brasília. DNPM/CPRM. 223 pp.

\section{NOTAS SOBRE OS AUTORES}

Edison Ramos Tomazzoli. Geólogo, formado pela Universidade Federal do Rio Grande do Sul (UFRGS). Mestre em Geologia pela Universidade de Brasília (UnB) e Doutor em Geologia pela mesma universidade. Realizou Pós-Doutorado pela Universidade Federal do Rio Grande do Sul (UFRGS). Atualmente é professor do Departamento de Geociências e do Programa de Pós-Graduação em Geografia da Universidade Federal de Santa Catarina (UFSC). As áreas de interesse são geoquímica, geomorfologia e minerais pesados.

Ulisses Rocha de Oliveira. Geógrafo formado pela Fundação Universidade Federal do Rio Grande (FURG) onde atuou na área de paleontologia do Quaternário costeiro e erosão costeira na província costeira do Rio Grande do Sul. Mestre em Geografia pela Universidade Federal de Santa Catarina (UFSC), onde atualmente faz doutorado. Atua na área de morfodinâmica de praias arenosas.

Norberto OImiro Horn Filho. Geólogo formado pela Universidade do Vale do Rio dos Sinos (UNISINOS), Mestre em Geociências pela Universidade Federal do Rio Grande do Sul (UFRGS) e Doutor em Geociências pela Universidade Federal do Rio Grande do Sul. Atualmente é professor do Departamento de Geociências e do Programa de Pós-graduação em Geografia da Universidade Federal de Santa Catarina (UFSC). As áreas de interesse são geologia costeira, morfodinâmica e sedimentologia de ambientes praiais. 